\title{
Parasitic nematodes of anseriform birds in Hokkaido, Japan
}

\author{
T. YOSHINO ${ }^{1}$, J. UEMURA ${ }^{1}$, D. ENDOH ${ }^{2}$, M. KANEKO ${ }^{3}$, Y. OSA $^{4}$, M. ASAKAWA ${ }^{1 *}$
}

\begin{abstract}
${ }^{1}$ Department of Pathobiology, School of Veterinary Medicine, Rakuno Gakuen University, Ebetsu, Hokkaido 0698501, Japan, *E-mail: askam@rakuno.ac.jp; ${ }^{2}$ Department of Health and Environmental Sciences, School of Veterinary Medicine, Rakuno Gakuen University, Ebetsu, Hokkaido 069-8501, Japan; ${ }^{3}$ Faculty of Environmental System, Rakuno Gakuen University, Ebetsu, Hokkaido 069-8501, Japan; ${ }^{4}$ Hokkaido Institute of Environmental Sciences, Sapporo, Hokkaido 060-0819, Japan
\end{abstract}

\begin{abstract}
Summary
Parasitic nematodes of 176 individuals of 15 bird species belonging to the order Anseriformes from Hokkaido, Japan were investigated. A total of 12 nematode species were obtained, namely Amidostomum anseris, A. acutum, Epomidiostomum crami, E. uncinatum, Tetrameres fissispina, Eucoleus contortus, Capillaria anatis, Baruscapillaria mergi, Contracaecum rudolphii, Echinuria uncinata, Streptocara crassicauda and Sarconema eurycerca. Among these, E. uncinatum (hosts: Anas platyrhynchos, A. poecilorhyncha, A. acuta, Mel. nigra) and E. crami (hosts: Anser albifroms, Ans. fabalis, C. cygnus, C. columbianus) were the first geographical records in Japan. There appeared to be strict host-parasite relationships between the wild swans/geese and A. anseris/E. crami, and between wild duck species and A. acutum/E. uncinatum, respectively.
\end{abstract}

Key words: Anseriformes; parasitic nematodes; first geographical records; Japan

\section{Introduction}

The most northern part of Japan, Hokkaido, is situated on the East Asian Flyway and is an important transit area for migratory waterfowls belonging to the order Anseriformes during stopovers on migration and during the main winter period (Miyabayashi, 1994). Because of the annually shrinking habitats for waterfowls in Hokkaido, there is a greatly increased risk of infectious disease outbreak, such as fatal nematodiasis, and death en mass (Ryšavý et al. 1982; Friend \& Franson, 1999; Asakawa et al., 2002; Kavetska, 2006). A preliminary survey of parasitic nematodes in waterfowls was carried out by Nakamura and Asakawa (2001) using materials derived from 30 individuals and the central part of the island. Between 2003 and 2006, we carried out a detailed survey over all of Hokkaido and obtained much new data. Among the nematode spe- cies obtained, redescriptions of 4 species belonging to the genera Amidostomum Railliet and Henry, 1909 and Epomidiostomum Skrjabin, 1915, regarded as highly pathogenic agents in waterfowls, (Friend \& Franson, 1999) were achieved as a base for future studies.

\section{Materials and methods}

A total of 176 carcasses of 15 anseriform species, Anser albifrons (Scopoli, 1769) $(\mathrm{n}=9)$, A. fabalis (Latham, 1787) ( $\mathrm{n}=2)$, Cygnus cygnus (Linnaeus, 1758) $(\mathrm{n}=45)$, C. columbianus (Ord, 1815) $(\mathrm{n}=24)$, Aix galericulata (Linnaeus, 1758) $(\mathrm{n}=2)$, Anas platyrhynchos (Linnaeus, 1758) $(\mathrm{n}=24)$, A. poecilorhyncha (Forster, 1781) $(\mathrm{n}=18)$, A. crecca (Linnaeus, 1758) ( $\mathrm{n}=21)$, A. penelope (Linnaeus, 1758) $(\mathrm{n}=4), A$. acuta (Linnaeus, 1758) $(\mathrm{n}=$ 6), Aythya fuligula (Linnaeus, 1758) $(\mathrm{n}=4)$, A. marila (Linnaeus, 1761) $(\mathrm{n}=8)$, Melanitta nigra (Linnaeus, 1758) $(\mathrm{n}=5)$, Bucephala clangula (Linnaeus, 1758) $(\mathrm{n}=3)$ and Mergus merganser (Linnaeus, 1758) $(\mathrm{n}=1)$ were collected between July 2003 and November 2006 in Hokkaido, Japan. The carcasses came from local governmental or private rescue centers, zoological gardens and animal hospitals. Helminthological examinations were performed in the Wild Animal Medical Center (WAMC) of Rakuno Gakuen University, Japan. All visceral organs of the carcasses were examined under a binocular microscope, and about $5 \mathrm{~g}$ of pectoral muscle tissue of each individual was examined for Trichinella larvae with thick glass plates. Parasitic nematodes were preserved and sorted in fixed $70 \%$ ethanol solution and cleared in lactophenol solution for morphological examination.

Morphological and metrical data based on 10 individuals of each trichostrongylid species were obtained with a camera lucida (OLYMPUS Model BH-2DA). All nematode specimens are preserved in the WAMC or the Meguro Parasitological Museum, Tokyo, Japan. 
Table 1: Parasitic nematodes obtained from Anseriforme

\begin{tabular}{|c|c|c|c|c|c|c|c|}
\hline \multirow{2}{*}{ Parasitic nematodes } & \multirow{2}{*}{ Site } & \multirow{2}{*}{ Host } & \multicolumn{2}{|c|}{ Prevalence } & \multicolumn{3}{|c|}{ Intensity } \\
\hline & & & Infected & $\%$ & mean & SD & range \\
\hline \multicolumn{8}{|l|}{ Order Enoplida } \\
\hline \multicolumn{8}{|l|}{ Superfamily Trichrioidea } \\
\hline \multicolumn{8}{|l|}{ Family Capillariidae } \\
\hline \multirow[t]{6}{*}{ Eucoleus contortus } & oe & Cygnus cygnus & 2 & 4.45 & 3 & 2.83 & $1-5$ \\
\hline & oe & C. columbianus & 6 & 25 & 3.67 & 3.72 & $1-11$ \\
\hline & oe & Anas platyrhynchos & 4 & 16.67 & 16.75 & 25.75 & $1-55$ \\
\hline & oe & A. poecilorhyncha & 3 & 16.67 & 2.33 & 1.53 & $1-4$ \\
\hline & oe & A. crecca & 1 & 4.76 & 5 & - & 5 \\
\hline & oe & Aythya marila & 2 & 25 & 1.5 & 0.71 & $1-2$ \\
\hline \multirow[t]{3}{*}{ Capillaria anatis } & si & C. columbianus & 2 & 8.33 & 3 & - & 3 \\
\hline & si & A. platyrhynchos & 2 & 8.33 & 2.5 & 0.71 & $2-3$ \\
\hline & si & A. poecilorhyncha & 7 & 38.89 & 1.57 & 0.79 & $1-3$ \\
\hline \multirow[t]{4}{*}{ Baruscapillaria mergi } & si & C. cygnus & 4 & 8.89 & 8 & 7.07 & $3-18$ \\
\hline & si & Ay. fuligula & 1 & 25 & 1 & - & 1 \\
\hline & si & Ay. marila & 3 & 37.5 & 2.67 & 2.08 & $1-5$ \\
\hline & si & Mergus merganser & 1 & 100 & 1 & - & 1 \\
\hline \multicolumn{8}{|l|}{ Order Strongylida } \\
\hline \multicolumn{8}{|l|}{ Superfamily Strongyloidea } \\
\hline \multicolumn{8}{|l|}{ Family Amidostomatidae } \\
\hline \multirow[t]{4}{*}{ Amidostomum anseris } & gi & Anser albifroms & 7 & 77.78 & 16 & 21.5 & $1-60$ \\
\hline & gi & Ans. fabalis & 2 & 100 & 13 & 14.14 & $3-23$ \\
\hline & gi & C. cygnus & 26 & 57.78 & 9.23 & 16.1 & $1-83$ \\
\hline & gi & C. columbianus & 19 & 79.17 & 17.25 & 27.93 & $1-125$ \\
\hline \multirow[t]{9}{*}{ A. acutum } & gi & Aix gareliculata & 1 & 50 & 1 & - & 2 \\
\hline & gi & A. platyrhynchos & 14 & 58.33 & 11.57 & 11.06 & $2-40$ \\
\hline & gi & A. poecilorhyncha & 10 & 55.56 & 4.7 & 5.31 & $1-17$ \\
\hline & gi & A. crecca & 7 & 33.33 & 3.29 & 3.25 & $1-10$ \\
\hline & gi & A. penelope & 3 & 75 & 1.33 & 0.58 & $1-2$ \\
\hline & gi & Ay. fuligula & 1 & 25 & 5 & - & 5 \\
\hline & gi & Ay. marila & 4 & 50 & 18.25 & 24.68 & $3-55$ \\
\hline & gi & Melanitta nigra & 4 & 80 & 7.35 & 3.5 & $3-11$ \\
\hline & gi & Bucephala clangula & 1 & 33.3 & 1 & - & 1 \\
\hline \multicolumn{8}{|l|}{ Family Trichostrongylidae } \\
\hline \multirow[t]{4}{*}{ Epomidiostomum crami } & gi & Ans. albifroms & 6 & 66.67 & 4.83 & 7.5 & $1-20$ \\
\hline & gi & Ans. fabalis & 2 & 100 & 3 & - & 3 \\
\hline & gi & C. cygnus & 6 & 13.33 & 2.83 & 2.79 & $1-8$ \\
\hline & gi & C. columbianus & 4 & 16.67 & 3.5 & 3 & $1-7$ \\
\hline \multirow[t]{4}{*}{ E. uncinatum } & gi & A. platyrhynchos & 4 & 16.67 & 7.75 & 9.54 & $2-22$ \\
\hline & gi & A. poecilorhyncha & 2 & 11.11 & 2 & 1.41 & $1-3$ \\
\hline & gi & A. acuta & 1 & 20 & 1 & - & 1 \\
\hline & gi & Mel. nigra & 1 & 20 & 2 & - & 2 \\
\hline \multicolumn{8}{|l|}{ Order Ascaridida } \\
\hline \multicolumn{8}{|l|}{ Superfamily Ascaridoidea } \\
\hline \multicolumn{8}{|l|}{ Family Anisakidae } \\
\hline Contracaecum rudolphii & gi & M. merganser & 1 & 100 & 3 & - & 3 \\
\hline
\end{tabular}




\begin{tabular}{|c|c|c|c|c|c|c|c|}
\hline \multicolumn{8}{|l|}{ Superfamily Acuarioidea } \\
\hline Echinuria uncinata & $\mathrm{pr}$ & C. columbianus & 1 & 4.17 & 1 & - & 1 \\
\hline \multirow[t]{3}{*}{ Streptocara crassicauda } & gi & C. cygnus & 1 & 2.22 & 1 & - & 1 \\
\hline & gi & C. columbianus & 1 & 4.17 & 2 & - & 2 \\
\hline & gi & A. platyrhynchos & 1 & 4.17 & 3 & - & 3 \\
\hline \multicolumn{8}{|l|}{ Order Spirurida } \\
\hline \multicolumn{8}{|l|}{ Superfamily Habronematoidea } \\
\hline \multicolumn{8}{|l|}{ Family Tetrameridae } \\
\hline \multirow[t]{10}{*}{ Tetrameres fissispina } & $\mathrm{pr}$ & C. cygnus & 10 & 26.67 & 13.4 & 23.96 & $1-79$ \\
\hline & $\mathrm{pr}$ & C. columbianus & 17 & 70.83 & 97.24 & 158.93 & $1-600$ \\
\hline & $\mathrm{pr}$ & Aix gareliculata & 1 & 50 & - & - & 1 \\
\hline & $\mathrm{pr}$ & A. platyrhynchos & 9 & 37.5 & 9.56 & 11.26 & $1-36$ \\
\hline & $\mathrm{pr}$ & A. poecilorhyncha & 4 & 22.22 & 2.75 & 2.87 & $1-7$ \\
\hline & $\mathrm{pr}$ & A. crecca & 2 & 9.52 & 1.5 & 0.71 & $1-2$ \\
\hline & $\mathrm{pr}$ & A. acuta & 1 & 20 & 1 & - & 1 \\
\hline & $\mathrm{pr}$ & Ay. fuligula & 2 & 50 & 7.5 & 3.54 & $5-10$ \\
\hline & $\mathrm{pr}$ & Ay. marila & 5 & 62.5 & 23.6 & 21.66 & $5-60$ \\
\hline & $\mathrm{pr}$ & B. clangula & 2 & 66.67 & 5.5 & 3.54 & $3-8$ \\
\hline \multicolumn{8}{|l|}{ Superfamily Filarioidea } \\
\hline \multicolumn{8}{|l|}{ Family Onchocercidae } \\
\hline Sarconema eurycerca & $\mathrm{hm}$ & C. columbianus & 2 & 8.33 & 5.5 & 9.45 & $2-9$ \\
\hline
\end{tabular}

\section{Results and Discussion}

A total of 12 nematode species, namely Amidostomum anseris (Zeder, 1800), A. acutum (Lundahl, 1848), Epomidiostomum crami (Wetzel, 1931), E. uncinatum (Lundahl, 1848), Tetrameres fissispina (Diesing, 1861), Eucoleus contortus (Creplin, 1839), Capillaria anatis (Schrank, 1790), Baruscapillaria mergi (Madsen, 1945), Contracaecum rudolphii (Hartwich, 1964), Echinuria uncinata (Rudolphi, 1819), Streptocara crassicauda (Creplin, 1829) and Sarconema eurycerca (Wehr, 1939) were obtained from the esophagus, intestines and heart muscles of 134 individual avians (Table 1), but no Trichinella larvae were observed in the present survey. Among them, the nematodes of the Amidostomatidae Travassos, 1919, subfamilies Amidostomatinae and Epomidostomatinae, were the most commonly encountered. All avian species examined excluding M. merganser were hosts for Amidostomum and/or Epomidiostomum. Two trichostrongylid species belonging to each genus, namely $A$. anseris, $A$. acutum, E. crami and E. uncinatum, were obtained. These species seem to be highly pathogenic agents. Although there have been excellent taxonomic studies of the species in Europe and Russia (Skrjabin et al., 1951; McDonald, 1974; Ryšavý et al., 1982; Barus et al., 1978; Petrova, 1987, 1989; Lomakin, 1991, 1993; Kavetska, 2006), there have not been sufficiently full morphological descriptions of these species in Asia including Japan. Hence, figures of the species (Figs $1-3$ ) are given. Furthermore, there appeared to be strict host-parasite relationships between the wild swans/geese and $A$. anseris/E. crami, and between wild duck species and $A$. acutum/E. uncinatum, respectively. Since both Amidostomum and Epomidiostomum are regarded as highly pathogenic agents for Anseriformes (Ryšavý et al., 1982; Friend \& Franson 1999; Kavetska, 2006), more detailed and systematic epidemiological sur-
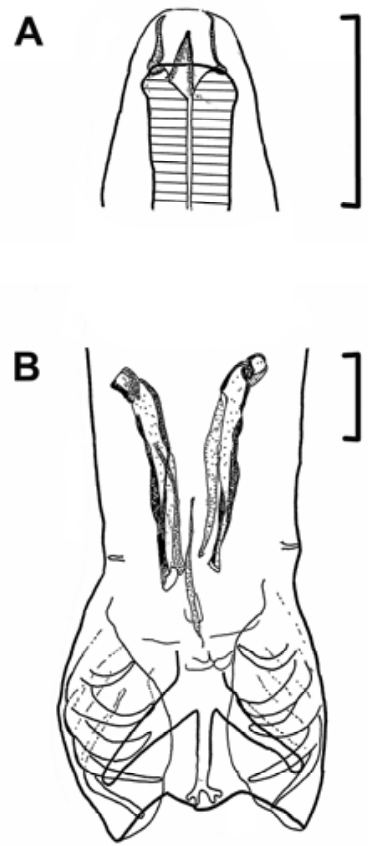

Fig. 1. Amidostomum acutum: 1A-Anterior extremity of male, lateral view; 1B-Bursa and spicules, ventral view (scale $=0.05 \mathrm{~mm})$ 

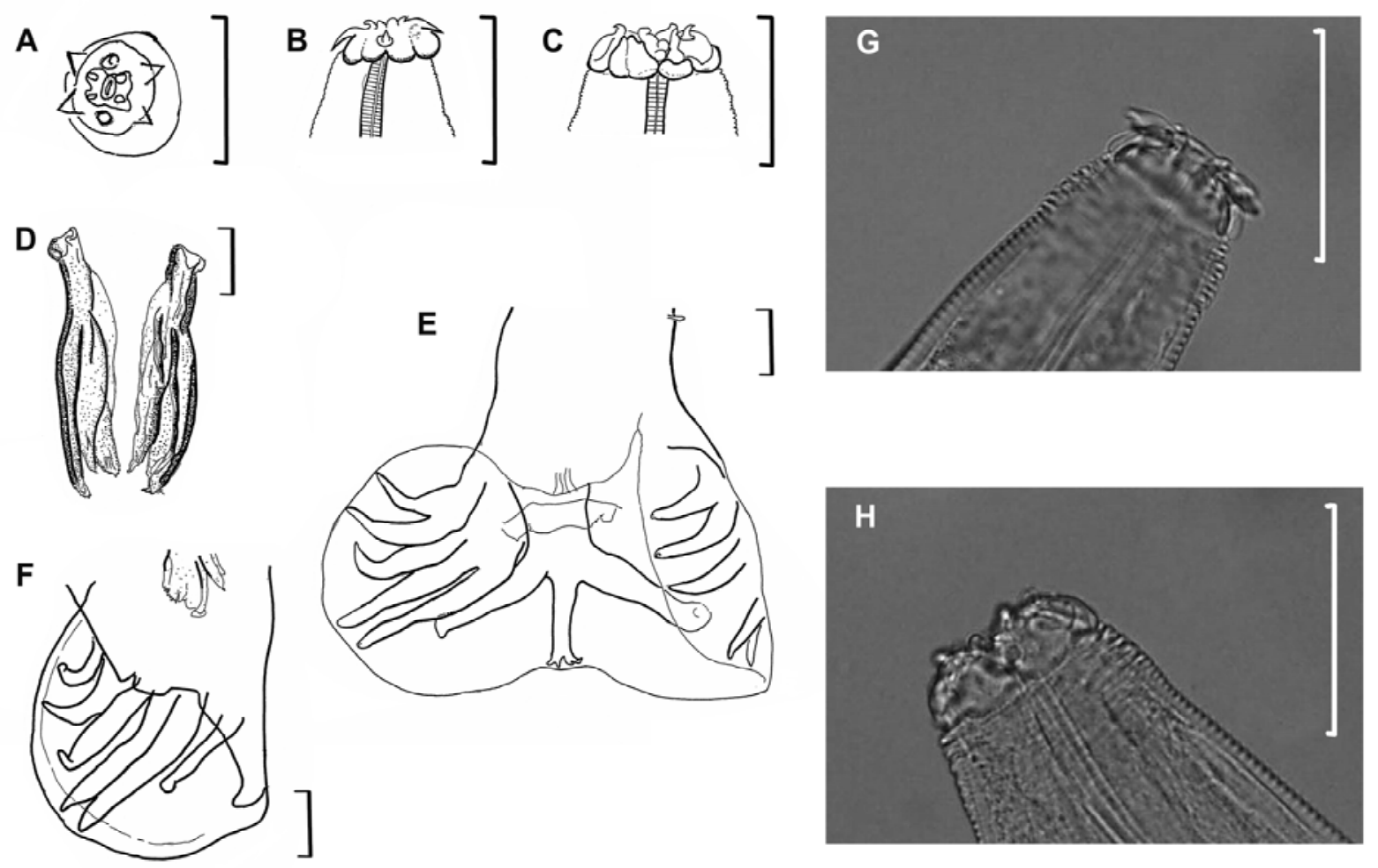

Fig. 2. A - E Epomidiostomum crami: A - anterior extremity of male, apical view, B - ibid, lateral view of normal type; C - ibid, abnormal type; D - spicules, ventral view; E - bursa, ventral view; F - bursa, lateral view, G - anterior extremity; lateral view of normal type, H - ibid; lateral view of abnormal type (scale $=0.05 \mathrm{~mm})$

veys are needed in the future. Therefore, the newly presented data, including morphology and host-parasite relationships, will be useful for surveys at sites on the East Asian Flyway and in the transit areas for the Anseriformes. Several nematode species in 5 genera have been reported in Anseriformes, including captive geese and ducks, from other islands in Japan, namely, Honshu and Kyushu (Yamaguti, 1941; Uchida et al., 1991; Sakamoto et al., 1995;
Nakano et al., 1996; Shimizu et al., 2000; Nakamura et al., 2003). These are Baruscapillaria Moravec, 1982 (although Nakamura and Asakawa (2001) recorded Pseudocapillaria mergi, Baruš and Sergeeva (1990) transferred this species in the genus Baruscapillaria), Contracaecum, Tetrameres (Creplin, 1846), Physaloptera (Rudolphi, 1819) and Amidostomum, all reported from Hokkaido (Nakamura and Asakawa, 2001). Hence for the order Anseriformes, the
A

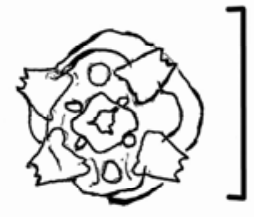

D

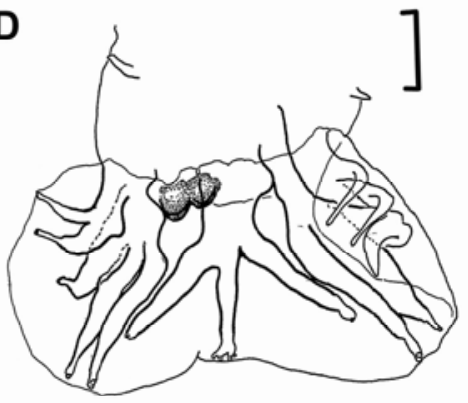

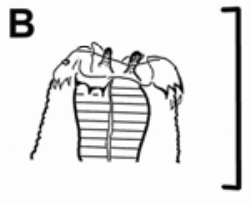

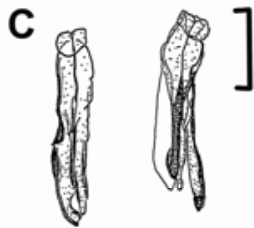

E

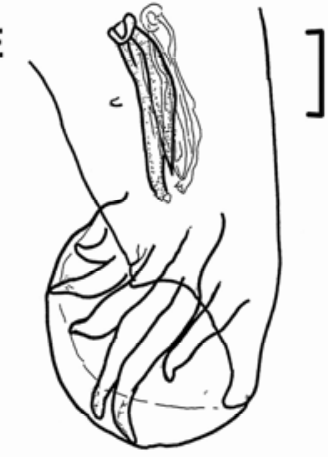

Fig. 3. Epomidiostomum uncinatum: A - anterior extremity of male, apical view; B - ibid, lateral view; C - spicules, ventral view, $\mathrm{D}$ - bursa, ventral view, E - bursa, lateral view (scale $=0.05 \mathrm{~mm}$ ) 
genus Streptocara (Railliet, Henry and Sisoff, 1912) was the first host record in Japan. Other genera, Eucoleus (Dujardin, 1845), Capillaria Zeder, 1800, Echinuria Soloviev, 1912, and Sarconema Wehr, 1939 in the present survey are the first local records from Hokkaido. Both Echinuria and Streptocara are spirurid nematodes, with a cosmopolitan distribution, are well known to cause severe esophagitis and ventriculitis, and have resulted in fatalities in wild and domestic waterfowl (Boughton, 1969; Fox et al., 1974; Griffiths et al., 1985; Sterner and Stackhouse, 1987; Mason, 1988; Work et al., 2004; Bano et al., 2005). Streptocara is known as a facultative agent in other waterfowls and gallinaceous birds. For example, even in Japan, Yamaguti (1935) reported S. recta (Linstow, 1879) from Tachybaptus ruficollis (Pallas, 1764) (Podicipediformes) and Yokohata (2002) reported S. crassicauda from Cerorhinca monocerata (Pallas, 1811) (Charadriiformes) and Gavia pacifica (Lawrence, 1858) (Gaviiformes). In the Slovak Republic, Berza (1958) reported S. pectinifera (Newmann, 1900) from Gallus gallus (Linnaeus, 1758). However, the present finding of $S$. crassicauda is the first host record of the order Anseriformes in Japan. Indeed, $C$. cygnus and $C$. columbianus are new host species for this nematode species, on a worldwide basis. The filariid nematode Sarconema eurycerca is well known as heartworm, sometime causing death in wild swans and geese (Holden \& Sladen, 1968; Sonin et al., 1974; Macneill, 1975; Friend \& Franson, 1999). Sakamoto et al. (1995) reported $S$. eurycerca from $C$. cygnus in Honshu, but in Hokkaido, this nematode species was obtained from $C$. columbianus.

\section{Acknowledgments}

The present survey was supported in part by the Environmental Technology Development Fund (Kiso 3) and the Global Environment Research Fund (F-062, 2006-2008) of the Ministry of the Environment, and a Grant-in-Aid (Nos. $18510205,20380163)$ of the Ministry of the Education, Science and Culture, Japan.

\section{References}

Asakawa, M., NaKamura, S., Brazil, M. A. (2002): An overview of infectious and parasitic diseases in relation to the conservation biology of the Japanese avifauna. J. Yamashina Inst. Ornithol., 34: 200 - 221

Bano, L., Natale, A., Vascellari, M., Comin, D., Mutinelli, F., Agnoletti, F. (2005): First report of parasitic esophagitis by Streptocara incognita in Muscovy ducks (Cairina moschata domestica) in Italy. Avian Dis., 49: $298-300$

Baruš, V., Sergeeva, T. P. (1990): Capillariids parasitic in birds in the palaearctic region (3) genus Baruscapillaria. Acta Sc. Nat. Brno., 24: 1 - 53

Baruš, V., Sergeeva, T. P., Sonin, M. D., Ryzhikov, K. M. (1978): Helminths of fish eating birds of the palaearctic region. I. Nematoda. Publishing House of the Czechoslo- vak Academy of Sciences, Prague

Boughton, E. (1969): On the occurrence of oesophageal worms, Streptocara crassicauda, in ornamental ducks in Hampshire. J. Helminthol., 43: 273 - 280

BREZA, M. (1958): Finding of Streptocara pectinifera (Newmann, 1900) nematode in č SR. Slov. vet. čas., 7: 187 - 190 (In Slovak).

Fox, J. G., SNyder, S. B., Schmidt, G. D., CAMPBell, L. H. (1974): Infection with the nematode Streptocara incognita in the Chilean flamingo. J. Wildl. Dis., 10: 66-69

Friend, M., Franson, J. C. (1999): Field Manual of Wildlife Diseases. USGS, Washington D. C., USA

Griffiths, G. L., Hopkins, D., Wroth, R. H., GAYNOR, W. (1985): Echinuria uncinata infection in mute swan cygnets (Cygnus olor). Austral. Vet. J., 62: 132

Holden, L. B., Sladen, W. J. L. (1968): Heart worm, Sarconema eurycerca, infection in whistling swans, Cygnus columbianus, in Chesapeake Bay. Bull. Wildl. Dis. Assoc., 4: $126-128$

KAVETSKA, K. M. (2006): Biological and ecological background of nematode fauna structure formation in the alimentary tracts of wild Anatinae ducks in North-Western Poland. Wydawnictwo akademii rolnicznej v Szczecine, Szczecin pp.1 - 128 (in Polish)

LOMAKIN, V. V. (1991): Revision of the family Amidostomatidae (Nematoda: Strongylida). Gelmintologija Zhivotnych, 38: 70 - 88 (in Russian)

LOMAKIN, V. V. (1993): Revision of the subfamily Amidostomatinae Travassos, 1919 (Amidostomatidae, Strongylida). In: Problems of helminth morfology, ecology and physiology. Trudy GELAN: 92 - 122 (in Russian).

Macneill, A. C. (1975): Heartworm, Sarconema sp. infection in a whistling swan, Olor columbianus. Can. Vet. $J ., 16: 82-83$

MASON, R. W. (1988): Laryngeal streptocariasis causing death from asphyxiation in ducks. Austral. Vet. J., 65: 335 $-336$

MCDonald, M. E. (1974): Key to Nematodes Reported in Waterfowl. Department of the Interior Bureau of Sport Fisheries and Wildlife Resource Publication, Washington D.C., USA

MiYABAYASHI, Y. (1994): Inventory of goose habitat in Japan. $1^{\text {st }}$ Ed. Japanese Association for Wild Geese Protection, Miyagi, Japan (in Japanese).

NAKAmURA, S., ASAKAWA, M. (2001): New records of parasitic nematodes from five species of the Anseriformes in Hokkaido, Japan. Jpn. J. Zoo Wildl. Med., 6: 27 - 33

Nakamura, S., Yoshino, T., Sato, J., ChibA, A., AsAKAWA, M. (2003): Parasitic helminthes from avian species in Niigata Pref., Japan. Jpn. J. Ornithol., 52: $116-$ 118 (in Japanese).

Nakano, Y., Mizusawa, T., Inoue, I., Mogami, S. (1996): Occurrence of internal parasites of waterfowl. In: Abstracts of the $122^{\text {nd }}$ Meeting of Japanese Society of Veterinary Medicine, Obihiro University, Obihiro: 113 (in Japanese).

Petrova, K. (1987): Species composition and morphology of the genus Amidostomum Railliet et Henry 1909 
(Strongylata: Amidostomatidae) in Bulgaria. Khelmintologiya, 24: 53 - 72 (in Bulgarian)

Petrova, K. (1989): Representatives of genus Epomidiostomum Skrjabin, 1915 (Nematoda: Amidostomatidae) met in Bulgaria: species comparison and morphology. Bul. Acad. Sci. Helminthol., 27: 20 - 32 (in Bulgarian, with English summary).

RYŠAVÝ, B., GROSCHAFT, J., BARUŠ, V., DVOŘÁKOVÁ, L. (1982): Helminth of water fowl. Key for determination, morphology, biology, laboratory diagnostics. Publ. House Academia, Prague (In Czech).

Sakamoto, T., Itagaki, T., Igarashi, T., OzeKi, T., KoJima, K., YoshinagA, H. (1995): Studies on parasites of swans. 2. Sarconema eurycerca and its pathogencity. Jpn. J. Parasitol., 44: 487 (In Japanese).

Shimizu, M., InOue, I., AsAno, H. (2000): Prevalence of parasitic fauna in digestive tracts of Aigamo ducks in Japan. J. Jpn. Vet. Med. Assoc., 53: 367 - 371 (in Japanese, with English summary).

Skrjabin, K. I., Shikhobalova, N. P., Schulz, R. S., Popova, T. I., Boev, S. N. (1951): Key to Parasitic Nematodes. Volume III. Strongylata. Israel Program for
Scientific Translation, Jerusalem

Sonin, M. D. (1974): Filariata of animals and man and diseases caused by them. Part 1. Aproctoidea. Skrjabin K. I. ed. Essentials of Nematodology. Vol. 17. Israel Program for Scientific Translations, Jerusalem

Sterner, M. C., StACKhouse, L. (1987): Parasitic ulcerative ventriculitis in mallards (Anas platyrhynchos). J. Wildl. Dis., 23: 680 - 682

UChidA, A., UChidA, K., ItAgaki, H., Kamegai, S. (1991): Check list of helminth parasites of Japanese birds. Jpn. J. Parasitol., 40: 7 - 85

Work, T. M., Meteyer, C. U., Cole, R. A. (2004): Mortality in Laysan ducks (Anas laysanensis) by emaciation complicated by Echinuria uncinata on Laysan Island, Hawaii, 1993. J. Wildl. Dis., 40: $110-114$

YAMAGUTI, S. (1935): Studies on helminth fauna of Japan. Part 12. Avian nematodes I. Jpn. J. Zool., 6: $403-431$

YAMAGUTI, S. (1941): Studies on helminth fauna of Japan. Part 36. Avian nematodes II. Jpn. J. Zool., 9: 441 - 480

YokohatA, Y. (2002): Preliminary report on the parasitic helminth fauna of seabirds killed in the "Nakhodka" oil spill. Jpn. J. Benthol., 57: 90 - 94 (in Japanese) 